\title{
Komunikasi Guru dan Orang Tua Siswa dalam Mengoptimalkan Pembelajaran Pada Masa Pandemi di SDI Al-Ittihad Tukum Tekung Lumajang
}

\author{
Nur Chayati \\ Institut Agama Islam Negeri Jember \\ nurchayati057@gmail.com
}

\begin{abstract}
One of the keys to the successful implementation of the learning process during the COVID-19 pandemic is intensive communication between teachers and parents. Because without communication there will be obstacles because elementary school students still need the guidance of teachers and parents. The purpose of this study was to describe the communication between teachers and parents in optimizing learning during the pandemic at SDI Al-Ittihad Tukum Tekung Lumajang. This study uses a phenomenological qualitative approach. Collecting data in this study using interviews and documentation. To test the validity of the data obtained, the researcher used triangulation of data sources and triangulation of methods. The results of this study are: 1) Communication between teachers and parents at SDI Al-Ittihad during the covid 19 pandemic in carrying out the teaching and learning process using the sambang teacher program, namely visiting students' homes to carry out the learning process. Sometimes making small study groups of about 2-3 children per group which is carried out at students' homes and accompanied by their respective class teachers so that communication between teachers, parents, and students is more closely related. In addition, communication between teachers and parents is to form a whatsapp group for each class. 2) Obstacles or challenges faced by teachers and parents during the COVID-19 pandemic are limitations in using mobile phones, increased expenses due to having to buy quotas, and availability of network/internet signals..
\end{abstract}


Nur Chayati, Komunikasi Guru dan Orang tua Siswa dalam Mengoptimalkan Pembelajaran Pada Masa Pandemi di SDI Al-Ittihad Tukum Tekung Lumajang

DOI: htts://doi.org/10.19105/rjpai.v2i2.4774

\section{PENDAHULUAN}

Di berbagai wilayah belahan dunia, Covid 2019 (Corona virus) telah menyerang negara di dunia ini sekitar 219 negara, hal ini berpengaruh pada berbagai bidang, salah satunya pada bidang pendidikan, khususnya bagi sekolah dasar. Cara memerangi virus Corona, pemerintah telah mengklaim daerah lokal untuk menyelesaikan pemisahan sosial (social distancing) dan menjaga jarak (physical distancing), memakai masker dan mencuci tangan. Dalam surat edaran kementerian dan pendidikan dan kebudayaan, Pemerintah Republik Indonesia telah memberitahu lembaga untuk tidak menerapkan pembelajaran tatap muka namun dapat dilakukan secara daring. ${ }^{1}$

Hasil pembelajaran daring ini bisa jadi tidak signifikan seperti hubungan langsung antara pendidik dan siswa dan bahkan antar siswa itu sendiri. Dengan minimnya hubungan ini dapat menghambat terwujudnya hasil belajar dalam proses belajar mengajar. Suasana belajar saat ini berubah menjadi suasana baru dalam siklus pembelajaran bahkan dirasakan oleh pendidik dan peserta didik.

Keadaan saat ini bisa menjadi tantangan utama dalam dunia sekolah untuk merencanakan siswa melalui kegaitan pembelajaran bagi peranannya di masa mendatang. "Belajar tergantung pada kepentingan leksikal yang berarti proses, cara, perbuatan pembelajaran ". Dalam proses pembelajaran keberhasilan pelajar tidak hanya bergantung pada proses belajar, tetapi itu juga bergantung pada komponen siswa itu sendiri. Mengingat hasil yang baik itu dipengaruhi oleh segmen yang berbeda, dan terutama bagaimana caranya aktivitas belajar siswa sebagai subjek belajar. ${ }^{2}$

Kemajuan sekolah dan masyarakat memiliki pengaruh penting untuk hasil interaksi instruktif. Awal sekolah dimulai dari keluarga sebelum memasuki cara pembelajaran formal. Ketika siswa telah memasuki jalur sekolah yang benar, itu tidak berarti bahwa tanggungjawab sepenuhnya beralih ke guru. Peran orang tua juga sangat menentukan tingkat kemajuan anak-anak dalam pendidikan. ${ }^{3}$

1 Putri, A. P., Rahhayu, R. S., Meidawati, S., \& Ningsih, P. A. R. Strategi Pembelajaran Melalui Daring Dan Luring Selama (Prima Magistra: Jurnal Ilmiah Kependidikan, 2021), hlm. 1-8.

2 Kusumawati, N. M. Optimalisasi Model Pembelajaran Berbasis Masalah dengan Berbantuan Lembar Kerja Siswa (LKS) untuk Meningkatkan Aktivitas dan Hasil Belajar Dalam Mata Pelajaran Matematika. (Journal of Education Action Research, 1(3), 2017), hlm. 197.

${ }^{3}$ Megawati, M., \& Kahar, F. Pengaruh Komunikasi Orang Tua Dengan Guru terhadap Peningkatan Kualitas Pembelajaran (Jurnal Office, 2017), hlm. 33. 
RABBANI

Penelitian ini dilakukan di SDI Al-Ittihad Tukum Kecamatan Tekung Kabupaten Lumajang. Dalam penelitian ini penulis akan mendeskripsikan terkait upaya komunikasi guru dan orang tua siswa dalam rangka optimalisasi pembelajaran selama pandemi covid-19. Dengan model pembelajaran daring, tentu komunikasi intensif antara orang tua dan guru menjadi salah satu kunci sukses terselenggaranya proses pembelajaran. Sebab tanpa komunikasi intensif tentu suksesnya pembelajaran akan sangat terkendala, mengingat secara psikis siswa sekolah dasar sangat perlu bimbingan dan pendampingan baik dari guru maupun orang tua.

Komunikasi interpersonal dalam keluarga merupakan unsur yang penting dalam keluarga, karena orang tua dengan anak memiliki keterikatan yang dapat menumbuhkembangkan individu, komunikasi yang diharapkan adalah komunikasi yang layak. Komunikasi yang layak dapat menimbulkan adanya perhatian, menyenangkan, berdampak pada mentalitas, hubungan dan aktivitas yang lebih baik seperti halnya dalam aktivitas yang dilakukan demikian juga dalam lingkungan sekitar, dipercaya bahwa komunikasi yang menarik akan dilakukan di antara orang tua dan anak-anak, sehingga hubungan yang menyenangkan akan terjadi. Peran orang tua dalam keluarga sangat penting untuk perkembangan fisik, wawasan, perspektif, perilaku, dan jasmani anak. Perkembangan anak dalam keluarga bergantung pada peran kedua orang tua dalam mengatur, mengasihi, menyayangi dan benar-benar fokus pada anak mereka untuk tumbuh dewasa. Seorang anak bayi menyerupai kertas putih tanpa goresan tinta. Di sinilah peran orang tua dalam membimbing anak-anak agar memiliki kapasitas yang lebih baik. Ini seperti ditegaskan dalam hadits bahwa "anakanak muda dibawa ke dunia dalam kondisi alamiah. Kedua orangtuanya menjadikannya Yahudi, Kristen dan Majus ...". Artinya, orang tua membentuk karakter anak menjadi pribadi yang islami sesuai dengan permintaan syar'i. ${ }^{4}$

Tanggung jawab pendidikan yang harus diperhatikan dan didukung oleh orang tua terhadap anak-anaknya antara lain: ${ }^{5}$

\footnotetext{
${ }^{4}$ Baharuddin, Pengaruh Komunikasi Orang Tua Terhadap Perilaku Anak Pada Min I Lamno Desa Pante Keutapang Aceh Jaya (Jurnal AL-IJTIMAIYYAH: Media Kajian Pengembangan Masyarakat Islam, 2019), hlm. 105-123.

${ }^{5}$ M. Nazarudin, Pola Kerjasama Guru dan Orang Tua dalam Meningkatkan Mutu Pendidikan di MIN 2 Kota Palembang (Intizar, 2018), hlm. 9-16.
} 
Nur Chayati, Komunikasi Guru dan Orang tua Siswa dalam Mengoptimalkan Pembelajaran

Pada Masa Pandemi di SDI Al-Ittihad Tukum Tekung Lumajang

DOI: htts://doi.org/10.19105/rjpai.v2i2.4774

RABBANI

1. Menunjang dan membesarkannya, tugas ini merupakan ciri motivasi untuk berpuas diri dengan alasan anak tersebut membutuhkan makanan, minuman dan perawatan agar dapat hidup secara ekonomis.

2. Melindungi dan menjamin kesejahteraannya, baik secara nyata maupun mendalam dari berbagai penyakit atau resiko alam yang dapat membahayakan dirinya.

3. Ajari dia dengan berbagai informasi dan kemampuan yang berharga untuk kehidupannya di masa depan sehingga ketika sudah dewasa dia bisa berdiri sendiri dan membantu orang lain.

4. Memberikan pendidikan agama kepada anak-anak sesuai ketentuan Allah SWT, sebagai tujuan akhir kehidupan muslim.

Proses pembelajaran diharapkan berhasil dan bernilai jika semua siswa secara efektif terlibat, secara intelektual, dan sosial dalam interaksi pembelajaran. Selain itu, siswa menunjukkan semangat belajar yang tinggi, keinginan yang luar biasa untuk belajar, dan rasa percaya pada diri sendiri. Kemudian dari sisi hasil, proses pembelajaran diharapkan dapat membuahkan hasil jika terjadi perubahan perilaku yang positif pada semua siswa. Proses pembelajaran diharapkan bermanfaat dan bernilai jika informasinya disesuaikan secara merata untuk menghasilkan banyak hasil dan kualitas terbaik, dan sesuai kebutuhan, perkembangan masyarakat dan pembangunan. 6

Pembelajaran berbasis daring yang memanfaatkan jaringan internet sesuai dengan aksesibilitas, konektivitas, fleksibilitas, dan kapasitas untuk menghasilkan berbagai jenis koneksi pembelajaran. Salah satu penelitian menunjukkan bahwa pemanfaatan internet dan inovasi media interaktif dapat mengubah cara penyampaian informasi dan dapat menjadi pilihan dibandingkan dengan penemuan yang dilakukan di kelas tradisional. Pembelajaran berbasis daring ini akan menemukan yang dapat mempersatukan siswa dan guru untuk melakukan kerjasama pembelajaran dengan bantuan internet. Pada tataran pelaksanaan, pembelajaran daring membutuhkan bantuan perangkat mobile, misalnya telepon seluler atau telepon Android, laptop, komputer, tablet, dan iphone yang dapat dimanfaatkan untuk mendapatkan data kapan

\footnotetext{
${ }^{6}$ Kulsum, D. U. Optimalisasi Penggunaan Buku Teks dalam Upaya Meningkatkan Prestasi Belajar di SMP (Jurnal Manajemen Pendidikan, 2015), hlm. 117-128.
} 
Nur Chayati, Komunikasi Guru dan Orang tua Siswa Dalam Optimalkan Pembelajaran Pada Masa Pandemi di SDI Al-Ittihad Tukum Tekung Lumajang DOI: htts://doi.org/10.19105/rjpai.v2i2.4774

RABBANI

pun dan di mana pun. Pembelajaran berbasis daring telah menjadi minat dalam bidang pengajaran sejak beberapa tahun terakhir. Pembelajaran berbasis daring diperlukan dalam pembelajaran pada periode transformasi modern 4.0.7

Hasil penelitian juga mengungkapkan bahwa tidak banyak siswa yang mengalami kesulitan memahami materi diskusi yang diberikan secara daring. Materi pelajaran umumnya disampaikan melalui bacaan yang tidak mudah dipahami secara menyeluruh oleh siswa. Mereka berpikir bahwa materi dan tugas tidak cukup karena perlu penjelasan dari guru. mengharapkan materi dan tugas yang kurang memadai karena membutuhkan klarifikasi langsung dari guru. Garrison dan Cleveland-Innes melaporkan bahwa kelas di mana guru secara teratur bergabung dan memberikan penjelasan memberikan pembelajaran lebih disukai daripada kelas di mana guru jarang pergi ke kelas dan memberikan penjelasan. ${ }^{8}$

\section{Pembahasan}

\section{A. Komunikasi Guru dan Orang Tua}

Istilah komunikasi sering digunakan oleh berbagai disiplin yang berlainlainan, sehingga dapat ditemukan istilah yang berbeda, misalnya dalam ilmu desain elektronik, komunikasi dicirikan sebagai hubungan antara dua fokus dengan menggunakan alat listrik. ${ }^{9}$

Sesuai dengan sifat imajinatifnya, komunikasi manusia merupakan siklus yang berkembang. Hal ini mengimplikasikan bahwa substansi dan karakter komunikasi serta faktor riil sosial yang dibuatnya terus berkembang dan mengalami perubahan sepanjang zaman. Ketika individu berbicara satu sama lain dari saat mereka berkumpul ke tingkat yang lebih dekat, komunikasi terus berubah, dan perkembangan inilah yang menawarkan bentuk pada hubungan yang sebenarnya. Jadi dengan cara ini, komunikasi

\footnotetext{
7 Sadikin, A., \& Hamidah, A. Pembelajaran Daring di Tengah Wabah Covid-19 (Biodik, 6(2), 2020), hlm. 109-119.

8 Ibid., hlm. 21.

9 Budi, R. Pengantar Ilmu Komunikasi. In Jurnal Pendidikan (I, Vol. 2, Issue 2). KRETAKUPA Print Makassar, 2017.
} 
Nur Chayati, Komunikasi Guru dan Orang tua Siswa dalam Mengoptimalkan Pembelajaran

Pada Masa Pandemi di SDI Al-Ittihad Tukum Tekung Lumajang

DOI: htts://doi.org/10.19105/rjpai.v2i2.4774

merupakan interaksi yang konsisten yang terus menerus mengubah diri kita dan dunia sosial kita. ${ }^{10}$

Hafied Cangara mengatakan dalam bukunya yang berjudul Pengantar Ilmu Komunikasi, bahwa untuk memenuhi fungsi komunikasi kita perlu terlebih dahulu memahami jenis-jenis komunikasi, karena dapat membedakan fungsi masing-masing, diantaranya: ${ }^{11}$

1. Jenis komunikasi dengan diri sendiri yang berfungsi menumbuhkan pikiran kreatifitas imajinasi, memahami dan mengendalikan diri, dan meningkatkan perkembangan deduksi sebelum memutuskan.

2. Jenis komunikasi antara pribadi yang berfungsi untuk meningkatkan hubungan manusia (human relation), menjauhi dan mengalahkan masalah pribadi, mengurangi kerentanan sesuatu hanya sebagai informasi dan keterlibatan pada orang lain.

3. Jenis komunikasi terbuka yang berfungsi untuk menumbuhkan semangat kebersamaan (solidaritas), mempengaruhi orang lain, memberi informasi, mengajar dan menghibur.

4. Jenis komunikasi masa yang berfungsi untuk menyebarkan informasi, meratakan pendidikan, menggerakkan perkembangan moneter dan menciptakan kebahagiaan dalam kehidupan seseorang.

Kemudian ada pendapat lain yang mengatakan bahwa, untuk membina kelancaran komunikasi perlu diperhatikan hal-hal yang cukup mempengaruhi antara lain: ${ }^{12}$

1. Secara lugas, mengimplikasikan bahwa setiap pesan atau data yang akan

10 A. Malik, Fungsi Komunikasi Antara Guru dan Siswa dalam Meningkatkan Kualitas Pendidikan (Studi Kasus Proses Belajar Mengajar pada SMP Negeri 3 Sindue). INTERAKSI: Jurnal Ilmu Komunikasi, 3(2), 2014), hlm. 168-173.

11 Baharuddin. Pengaruh Komunikasi Orang Tua Terhadap Perilaku Anak Pada Min I Lamno Desa Pante Keutapang Aceh Jaya (Jurnal AL-IJTIMAIYYAH: Media Kajian Pengembangan Masyarakat Islam, 5(1), 2019), hlm. 114.

12 Ibid., hlm. 118. 
Nur Chayati, Komunikasi Guru dan Orang tua Siswa Dalam Optimalkan Pembelajaran Pada Masa Pandemi di SDI Al-Ittihad Tukum Tekung Lumajang DOI: htts://doi.org/10.19105/rjpai.v2i2.4774

RABBANI

disampaikan oleh komunikator (orang tua) kepada komunikan (anak) harus diketahui dengan mudah sehingga komunikan sendiri memahami, mengerti atau dapat mengetahui apa yang telah disampaikan komunikator.

2. Tepat sasaran dan waktu, artinya dalam menyampaikan komunikasi komunikator (orang tua) atau komunikan (anak) harus pintar dalam memilih waktu dan tempat yang tepat, misalnya ketika orang tua memberikan arahan atau menegur anak, harus melihat keadaan atau situasi anak dalam kondisi yang mengizinkan orang tua melakukan ini atau tidak, dengan tujuan agar si anak tidak merasa gelisah, terkekang atau geram dalam menoleransi apa yang telah dilakukan orang tua dan sebaliknya antara anak dan orang tuanya.

3. Kepercayaan bersama, yang mengandung arti bahwa dalam suatu hubungan, khususnya antar orang tua dan anak, keduanya harus saling percaya, mengingat dengan adanya rasa saling percaya maka hubungan (komunikasi) antara orang tua dan anak benar-benar akan membuat hubungan yang lebih efektif dan efisien. Tentunya hal tersebut tidak lepas dari pengawasan, bimbingan, arahan dan pertimbangan dari orang tua untuk anak-anaknya.

4. Mengetahui situasi dan kondisi, menyiratkan bahwa komunikator (orang tua) harus mengetahui atau kondisi yang benar untuk menyampaikan pesan atau informasi kepada komunikator (anak).

Zakia Daradjat, sebagaimana dikutip Candra dan Sakban, menyebutkan beberapa faktor antara lain: pertama membuat pemahaman, yang diartikan sebagai pengakuan yang hati-hati atas dorongan tersebut sebagaimana yang direncanakan oleh komunikator. Kedua, membuat kegembiraan, yaitu membuat kedua belah pihak bersukacita karena kesepakatan dan kepentingan dasar yang sama. Yang ketiga mempengaruhi mentalitas, khususnya perspektif sesuai standar yang sesuai, khususnya pandangan yang positif. Keempat, menjalin hubungan sosial yang baik, khususnya 
Nur Chayati, Komunikasi Guru dan Orang tua Siswa dalam Mengoptimalkan Pembelajaran

Pada Masa Pandemi di SDI Al-Ittihad Tukum Tekung Lumajang

DOI: htts://doi.org/10.19105/rjpai.v2i2.4774

hubungan yang baik antara komunikator dan komunikan. Kelima tindakan yang baik, yakni tindakan persuasi sebagai tujuan komunikasi dari upaya mempengaruhi orang sekitar agar bertindak sesuai dengan yang diinginkan. ${ }^{13}$

Proses pengajaran dan pembelajaran antara guru dan siswa akan semakin memiliki bobot yang baik dengan sendirinya jika ada komunikasi yang dapat diterima antara keduanya, untuk situasi ini disebut mentrasnfer ilmu ke siswa. Kegiatan ini akan dibawakan dengan baik melalui pelaksanaan ketertiban dalam proses pengajaran dan pembelajaran dengan strategi pemberian teori di dalam ruangan dan arahan yang wajar di lapangan. Metode penyampaian guru dengan memanfaatkan bahasa yang mudah dipahami oleh siswa, membuat komunikasi ini berjalan dengan baik. Dengan memanfaatkan pola pembelajaran di luar kelas (praktik), siswa menjadi santai dan sibuk menerima latihan dengan baik. ${ }^{14}$

Hubungan antara guru dan orang tua dikaitkan dalam proses komunikasi yang unik, seperti dalam teori Sirkuler Osgood dan Schramm, dua faktor manusia dalamproses komunikasii interpersonal saling terkait untuk membentuk hubungan proporsional antara komunikator dan komunikan yang dikirim melalui encoding dan decoding dan menafsirkan proses menggunakan media berbasis internet sebagai saluran komunikasi interpersonal. Dalam proses komunikasi yang terjadi secara dinamis terdapat reaksi kritik antara komunikator dan komunikan, sehingga hubungan komunikasi interpersonal berjalan dengan baik dan dinamis. Keterkaitan antara guru dan orang tua siswa lebih ditegaskan dalam hubungan yang menyenangkan, baik terkait penyediaan informasi yang

13 Candra dan Sakban, Hubungan Antara Pola Komunikasi Orang Tua Dengan Motivasi Belajar Siswa di SMAN 1 Labuapi Lombok Barat (JUPE Jurnal Pendidikan Mandala, 2(2), 2017), hlm. 83.

14 A. Malik, Fungsi Komunikasi Antara Guru dan Siswa, hlm. 171. 
RABBANI

dibutuhkan oleh kedua belah pihak, pengawasan, dan lainnya dengan tujuan akhir untuk meningkatkan prestasi belajar siswa. ${ }^{15}$

Briggs dan Potter menjelaskan bahwa kerjasama antara sekolah dan orang tua diklasifikasikan menjadi dua, yaitu khususnya kontribusi dan dukungan orang tua. Kontribusi adalah tingkat dasar partisipasi, misalnya orang tua datang dan membantu sekolah setiap kali disambut sebagai pertemuan orang tua. Dukungan adalah tingkat kolaborasi yang lebih luas dan lebih tinggi. Orang tua dan sekolah duduk bersama memeriksa berbagai program dan kegiatan anak. Seperti yang ditunjukkan oleh Epstein, ada enam jenis kerjasama dengan orang tua, khususnya: parenting, komunikasi, volunteer, kontribusi orang tua dalam pembelajaran anak di rumah, dinamis, dan upaya bersama dengan masyarakat. Parenting adalah gerakan yang melibatkan keluarga dalam memperluas wawasan dan kemampuan mereka dalam memelihara untuk membangun lingkungan rumah yang mendukung perkembangan anak. Komunikasi adalah jenis sekolah ke rumah dan dari rumah ke kelas yang baik untuk memberitahukan tentang program sekolah dan kemajuan perkembangan anak. Komunikasi dilaksanakan untuk bertukar informasi antara sekolah dan orang tua. ${ }^{16}$

Selain dengan tegas memengaruhi anak-anak, masuknya orang tua dalam pembelajaran juga memberi keuntungan bagi sekolah. Dalam sebuah penelitian diketahui bahwa kontribusi orang tua dalam pembelajaran dapat meningkatkan semangat dan keberanian guru, peningkatan dukungan dari keluarga, hasil evaluasi guru oleh orang tua semakin tinggi, peningkatan prestasi siswa dan pada akhirnya meningkatkan kedudukan sekolah dalam komunitas pendidikan. Pendidik juga akan memiliki wawasan yang baik

15 A. S. Siolemba. Koordinasi Berbasis Media Sosial Antara Orang Tua dan Guru dalam Pengawasan Pembelajaran Siswa (Studi Kasus: SMP Kristen Satya Wacana Salatiga) (Artikel Ilmiah Repository UKSW, 2016), hlm. 6-7.

16 Ibid., hlm. 8. 
Nur Chayati, Komunikasi Guru dan Orang tua Siswa dalam Mengoptimalkan Pembelajaran

Pada Masa Pandemi di SDI Al-Ittihad Tukum Tekung Lumajang

DOI: htts://doi.org/10.19105/rjpai.v2i2.4774

RABBANI

tentang orang tua agar komunikasi antara pengajar dan orang tua berjalan dengan baik. ${ }^{17}$

Salah satu faktor yang mempengaruhi motivasi belajar siswa adalah komunikasi siswa dengan guru. Alice Tjandralila Rahardja mengungkapkan, komunikasi adalah penyampaian pikiran atau perasaan seseorang (komunikator) kepada individu yang dapat menyampaikan semua pesan tentang topik yang akan disampaikan dengan menggunakan bahasa yang mudah dipahami oleh siswa tentunya. Karena motivasi mendasar dibalik komunikasi adalah untuk memahami dan memahami apa yang disampaikan komunikator kepada komunikan. ${ }^{18}$

Ada contoh kerjasama antara pendidik dan wali di SDI Al Minhaaj yang dapat direncanakan sebagai berikut, hasil pemeriksaan menunjukkan bahwa peran pengajar di Al Minhaaj adalah memberikan inspirasi atau nasihat. Inspirasi diberikan agar siswa tetap bersemangat dalam bertindak hebat, sementara nasihat diberikan untuk mengatur siswa agar bertindak sebagaimana mestinya. Guru yang memiliki perilaku yang sesuai akan membuat siswa tertarik dengan apa yang mereka lakukan. Salah satu bentuk partisipasi orang tua dalam meningkatkan karakter adalah orang tua sebegai contoh atau model. Orang tua sebagai contoh baik dari aktivitas, perkataan, dan perilaku akan ditiru oleh anak-anak. Tingkah laku yang ditiru anak adalah tingkah laku yang mereka lihat, wawasan, dan rasakan, maka dari itu orang tua harus cermat dalam bertindak di depan anak. Pada usia tertentu, anak-anak tidak dapat menemukan cara untuk mengetahui aktivitas mana yang dapat diterima dan mana tindakan yang buruk untuk ditiru, jadi ketika orang tua bertindak harus hati-hati di depan anak-anak. Faktor yang mempengaruhi belajar menurut Purwanto adalah kematangan/

17 A. Pusitaningtyas, Pengaruh Komunikasi Orang Tua dan Guru terhadap Kreativitas Siswa (Proceedings of the ICECRS, 1(1), 2017), hlm. 938.

18 M. Sari, Ninghardjanti, P., \& Susilowati, T. Komunikasi Guru dengan Siswa dan Bimbingan Orang Tua terhadap Motivasi Belajar Siswa (Jurnal Pendidikan Administrasi Perkantoran, 2013), hlm. 2. 
Nur Chayati, Komunikasi Guru dan Orang tua Siswa Dalam Optimalkan Pembelajaran Pada Masa Pandemi di SDI Al-Ittihad Tukum Tekung Lumajang DOI: htts://doi.org/10.19105/rjpai.v2i2.4774

RABBANI

pengembangan, pengetahuan/wawasan, persiapan/tes, inspirasi, sifat-sifat pribadi seseorang, kondisi keluarga, pendidik dan cara mengajar, perangkat pembelajaran, inspirasi sosial, dan lingkungan/peluang. ${ }^{19}$

\section{B. Strategi Optimalisasi Pembelajaran}

Optimalisasi dalam bahasa adalah dorongan untuk terus meningkatkan latihan atau program yang ada. Sedangkan optimalisasi dalam pembelajaran, tepatnya interaksi, strategi, demonstrasi perampingan untuk mencari tahu bagaimana menjadi lebih baik dan optimal. (Publik, 2008) Siklus pembelajaran dapat efektif jika tujuan informatif eksplisit dapat dicapai. Mengenai petunjuk pencapaian siklus pembelajaran adalah sebagai berikut: Pertama, asimilasi bahan ajar yang diharapkan untuk mencapai prestasi tinggi baik secara kolektif maupun mandiri. Kedua, perilaku digambarkan secara eksplisit informatif atau tujuan pembelajaran yang telah dicapai oleh siswa baik kelompok atau individu. ${ }^{20}$

Pemberlakuan Undang-Undang Nomor 20 Tahun 2003 tentang Sistem Pendidikan Nasional, merupakan pencapaian penting persekolahan, karena pendidikan diartikan sebagai unsur yang melekat pada masyarakat, sehingga pada umumnya mereka dapat berupaya mengembangkan potensinya melalui siklus pembelajaran. Dan atau metode yang berbeda yang dikenal dan dirasakan oleh daerah setempat. Sesuai Permendiknas Nomor 16 Tahun 2007 tentang kualifikasi akademik dan kompetensi guru dalam menyelesaikan kewajiban pendidik harus memiliki empat kemampuan utama, yaitu: (1) keterampilan pedagogik adalah kemampuan pendidik untuk mengawasi pembelajaran bagi siswa, (2) kompetensi kepribadian adalah kemampuan kepribadian mantap, berkembang,

19 A. G. Prayoga, Benty, D. D. N., \& Kusumaningrum, D. E. Kerjasama Guru dan Orang Tua dalam Peningkatan Budi Pekerti Pesera Didik di SDI Plus Al Minhaaj Wates Kediri (Digital Repository Universitas Negeri Malang, 2017), hlm. 8.

${ }^{20}$ Ma`arif, M. A. (n.d.), Optimalisasi Pembelajaran Pendidikan Islam di Sekolah/Madrasah: Upaya dan Faktor Penghambat Pembelajaran Pendidikan Islam (Falasifa, 8(2), 2017), hlm. 273-274. 
Nur Chayati, Komunikasi Guru dan Orang tua Siswa dalam Mengoptimalkan Pembelajaran

Pada Masa Pandemi di SDI Al-Ittihad Tukum Tekung Lumajang

DOI: htts://doi.org/10.19105/rjpai.v2i2.4774

RABBANI berkarakter cerdas. Selain itu, berwibawa, menjadi teladan yang baik bagi siswa dan memiliki karakter yang terhormat, (3) keterampilan sosial adalah kemampuan guru sebagai komponen masyarakat untuk menyampaikan dan berbaur secara efektif dengan siswa, sesama pendidik, staf pengajar, orang tua, dan masyarakat yang melingkupinya. Dan, (4) kecakapan mahir adalah kemampuan untuk menguasai materi pembelajaran secara komprehensif dan mendalam yang memungkinkan mereka mengarahkan siswa untuk memenuhi pedoman kemampuan yang ditetapkan dalam Standar Nasional Pendidikan untuk meningkatkan mutu pengajaran sekolah. ${ }^{21}$

Pembelajaran saat ini mendorong terjadinya reorientasi dari model teching ke model pembelajaran yang berfokus pada siswa. Model ini menempatkan siswa sebagai subyek pembelajaran yang harus secara efektif membina diri. Kegiatan pembelajaran harus dikoordinasikan untuk membantu siswa pada tingkat kemampuan dasar sehingga mereka dapat mencapai tujuan yang ditetapkan. Sesuai dengan standar pembelajaran dan peningkatan kemampuan, setiap siswa harus diberikan kesempatan untuk mencapai tujuan yang ditunjukkan dengan kapasitas dan kecepatan belajar yang berbeda. 22

Untuk dapat memperlancar proses belajar mengajar peserta didik, guru perlu memperhatikan beberapa faktor, baik yang terkandung dalam siswa maupun faktor alam yang harus dikontrol. Faktor-faktor di luar siswa yang harus diperhatikan dengan alasan akan mempengaruhi siklus pembelajaran adalah (1) kondisi pembelajaran, (2) target pembelajaran, dan (3) pemberian masukan. ${ }^{23}$

21 A. Zaini, Optimalisasi Ketercapaian Standar Proses Pembelajaran untuk Meningkatkan Mutu Pendidikan di SMPN Pamekasan (Jurnal Pendidikan, 1(1), 2013), hlm 2.

${ }^{22}$ Syukri Fathudin Achmad Widodo, W. J. Upaya Dosen dalam Optimalisasi Pembelajaran Ditinjau dari Heterogenitas Karakteristik Mahasiswa (Journal of Chemical Information and Modeling, 53 (9), 1970), hlm. 3.

${ }^{23}$ Z. Matondang, Mengoptimalkan Mutu Proses Pembelajaran Matematika di Kelas (Jurnal Character Building, 2010), hlm. 6 
RABBANI

Atkinson yang dikutip oleh Baharuddin mengusulkan empat standar yang harus diperhatikan dalam pembelajaran, yaitu: ${ }^{24}$

1. Model proses pembelajaran

2. Penentuan model pembelajaran yang memuaskan

3. Penentuan tujuan pembelajaran

4. Skala perkiraan ditetapkan pada setiap tujuan pembelajaran.

Mengutip Muhammad Anas Ma'arif, ada beberapa cara yang dapat dilakukan oleh warga sekolah/madrasah dalam mengefektifkan proses pembelajaran, di antaranya:25

1. Penyamaran kualitas yang ketat di sekolah/madrasah. Hal inilah yang kerap kami tangkap dari upaya para warga sekolah/madrasah dalam membentuk siswa-siswi menjadi manusis seutuhnya, insan kamil, ulul albab. Internanilasi dengan kualitas yang ketat dapat diterapkan baik di sekolah, madrasah, pesantren atau di rumah. Jadi ada upaya yang dilakukan untuk menanamkan kualitas ini ke siswa.

2. Meningkatkan dan membina rencana kerangka kerja pembelajaran. Mengingat beberapa penelitian dan penemuan serta uji coba dari para ahli, ada beberapa bagian dalam model pembelajaran yang harus diperhatikan dalam menentukan teknik model pembelajaran. Segmen tersebut dapat digambarkan di bawah ini: 1) Menetapkan tujuan perubahan yang menjadi harapan bagi madrasah/sekolah Menentukan pendekatan dalam kurikulum 2013 metodologi yang digunakan adalah model pembelajaran logika interaksi, yaitu model yang dibuat bergantung pada metodologi logis . Pendekatan juga dapat diartikan sebagai sistem berwawasan yang dibuat dan diterapkan untuk memahami suatu masalah dan menjadi patokan untuk tatanan logis. Kepastian strategi mengambil bagian penting dalam menciptakan suasana yang membantu dalam pembelajaran.

24 M. A.Ma`arif (n.d.). Optimalisasi Pembelajaran Pendidikan Islam, hlm. 275.

25 Ibid., hlm. 279. 
Nur Chayati, Komunikasi Guru dan Orang tua Siswa dalam Mengoptimalkan Pembelajaran

Pada Masa Pandemi di SDI Al-Ittihad Tukum Tekung Lumajang

DOI: htts://doi.org/10.19105/rjpai.v2i2.4774

Ketepatan memilih strategi seperti yang ditunjukkan oleh pengetahuan siswa di sini sangat diperlukan.

3. Memperluas keterampilan guru dalam menguasai pembelajaran pendidikan adalah suatu kegiatan yang berguna. Oleh karena itu pencapaian interaksi pembelajaran dipengaruhi oleh beberapa komponen. Salah satunya adalah guru atau pendidik. Karena pendidik adalah sosok manusia yang memegang peranan penting dalam kegiatan pembelajaran.

Mengutip Wagiran, (meskipun dalam penulisannya berbicara tentang peran dosen namun dapat dilakukan pada guru sekolah dasar), memahami seperti yang ditunjukkan oleh dosen, sesuai dengan heterogenitas karakteristik siswa, meliputi:26

1. Menempatkan siswa/siswi sebagai subjek pembelajaran

2. Strategi pembelajaran disesuaikan dengan substansi pembelajaran dan fokus pada kualitas siswa. Teknik-teknik ini menggabungkan diskusi kecil yang heterogen, penggunaan modul, dan adanya peningkatan, pengembangan materi dan perbaikan.

3. Memanfaatkan media yang dapat meningkatkan kreativitas, latihan siswa,

dan up to date

4. kapasitas pemateri/pendidik menjadi fasilitator, motivator dan inspirator sehingga siswa/mahasiswa menjadi aktif

5. Hubungan dengan mahasiswa/siswa sebagai kaki tangan dan tidak menetapkan guru sebagai satu-satunya sumber informasi, koneksi yang tidak tertutup, menyenangkan dan saling aktif tanpa melupakan posisi khusus mereka, dan

6. Evaluasi menyeluruh, objektif, berdasarkan standar kemampuan dasar, kritik langsung, dan normal (disesuaikan).

26 Syukri Fathudin Achmad Widodo, W. J. Upaya Dosen Dalam Optimalisasi Pembelajaran, hlm. 1. 
Upaya untuk meningkatkan pembelajaran yang signifikan, pendidik harus memiliki pilihan untuk mengkonfigurasikan pembelajaran dengan mengefektifkan pemanfaatan media pembelajaran seperti yang diungkapkan oleh Asep Herry (2014) ketika guru menetapkan pilihan dalam perencanaan pembelajaran, sehingga ia perlu mempertimbangkan pengelompokan kesempatan belajar yang akan terjadi, di mana kesempatan belajar terjadi, jumlah waktu yang dimanfaatkan, dan "meningkatkan aset atau media pembelajaran yang digunakan dan materi yang digunakan". Media adalah mediator dari penyedia pesan (a source) ke penerima pesan ( $a$ receiver). Biasanya media terbagi menjadi dua komponen, yaitu komponen perangkat keras (hardware) atau peralatan dan komponen pesan yang disampaikannya (message/software). Sejalan dengan itu, media pembelajaran merupakan sekumpulan perangkat yang disusun oleh pengajar untuk digunakan dalam interaksi pembelajaran. Dalam pemilihan media pembelajaran ini, komponen penting yang harus disiapkan oleh pengajar adalah perangkat keras yang dapat memperkuat pemahaman siswa terhadap informasi yang didapat serta memiliki pilihan untuk mengubah perilaku atau memperkuat karakter. ${ }^{27}$

Pengoptimalan model pendidikan yang berdasarkan suatu persoalan merupakan salah satu pemicu perluasan aktivitas pembelajaran siswa. Pelaksanaan aktivitas pembelajaran yang menghubungkan masalah seharihari membuat siswa sadar bahwa apa yang mereka sadari sangat penting bagi kehidupan mereka. Ini, memunculkan ketertarikan dan kegembiraan dalam mempelajari sebuah pelajaran. Kegiatan yang dilakukan karena kesenangan melakukan kegiatan ini akan mengurangi rasa takut untuk melakukan suatu perubahan kemudian terus berusaha untuk meningkatkan kegiatan yang telah dilakukan. Aktivitas belajar akan bertambah jika

27 Sardjiyo, Optimalisasi Penggunaan Media Pembelajaran sebagai Wujud Inovasi Belajar yang Bermakna dalam Pengembangan Karakter Peserta Didik (Kasus Pembelajaran di SDN X Kabupaten Bandung) (Prosiding Temu Ilmiah Nasional Guru (TING) VIII, November, 2016), hlm. 501. 
Nur Chayati, Komunikasi Guru dan Orang tua Siswa dalam Mengoptimalkan Pembelajaran

Pada Masa Pandemi di SDI Al-Ittihad Tukum Tekung Lumajang

DOI: htts://doi.org/10.19105/rjpai.v2i2.4774

diimbangi dengan pertimbangan dan apresiasi atas karya terbaik yang telah diselesaikan oleh para siswa tersebut. Jadi tugas pendidik sebagai inspirasi sangat menentukan kenaikan aktivitas belajar siswa. ${ }^{28}$

Motivasi pemahaman belajar pada umumnya akan dipengaruhi oleh faktor-faktor luar, salah satunya adalah lingkungan keluarga, sehingga anakanak yang mendapatkan komunikasi positif memiliki prestasi belajar yang baik. Pengaruh luar memberikan kontribusi yang luar biasa bagi siswa, seperti yang diklarifikasi oleh Mudjiono (2014) bahwa motivasi belajar dipengaruhi oleh beberapa elemen, termasuk budaya sebagai acuan atau dasar yang dipegang oleh setiap orang untuk bertindak dalam keadaannya saat ini, keluarga tempat individu berinteraksi dengan orang lain. Jadi itu berdampak baik di antara keluarga sendiri, di sekolah atau tempat yang menjadi tempat proses belajar dan karakter individu. ${ }^{29}$

Selain komunikasi pendidik dengan siswa, faktor yang mempengaruhi motivasi belajar adalah arahan orang tua. Memberi motivasi bukan hanya tugas pendidik, namun pengarahan orang tua berperan penting dalam memberikan motivasi pembelajaran. Dengan arahan tersebut dipercaya dapat menumbuhkan semangat belajar anak. Arahan orang tua yang diberikan dapat melalui memberikan pengawasan dalam pergaulan, mengarahkan anak dalam belajar, membantu anak-anak dengan pekerjaan sekolah, membantu dalam menangani masalah-masalah di sekitarnya. Orang tua yang memiliki perhatian dengan pendidikan anaknya akan memberikan arahan sebaik mungkin kepada anak-anaknya untuk mencapai prestasi belajar yang terbaik. Anak-anak yang mendapatkan arahan dan kasih sayang dari orang tuanya akan membuat mereka merasa benar-benar fokus, dengan cara ini mendorong energi untuk mencari tahu bagaimana mencapai prestasi dalam belajar. Sebaliknya. Selain itu, orang tua harus berupaya menciptakan lingkungan belajar yang bermanfaat dalam

28 N. M. Kusumawati, Optimalisasi Model Pembelajaran Berbasis Masalah, hlm. 206.

29 Candra dan Sakban, Hubungan antara Pola Komunikasi Orang Tua, hlm. 83. 
RABBANI

lingkungan keluarga, mengingat lingkungan keluarga sangat mempengaruhi semangat belajar anak-anak di rumah. ${ }^{30}$

Setiap siswa tentunya memiliki perbedaan yang unik, misalnya dalam hal pengetahuan, hobi, kemampuan, latar belakang keluarga, sifat, dan kebiasaan. Pendidik tidak seharusnya menganggap siswa seolah-olah semua siswa adalah sama. Jika perbedaan individu siswa direnungkan dan digunakan secara tepat, kecepatan dan prestasi belajar siswa dapat diciptakan. ${ }^{31}$

\section{METODE PENELITIAN}

Jenis penelitian ini merupakan penelitian empiris (field research) dengan pendekatan kualitatif fenomenologis, dengan teknik pengumpulan data menggunakan metode wawancara dan dokumentasi. Pengecekan keabsahan data dalam penelitian ini menggunakan triangulasi sumber data dan triangulasi metode. Penelitian ini berlokasi di SDI Al-Ittihad Desa Tukum Kecamatan Tekung Kabupaten Lumajang.

\section{HASIL DAN PEMBAHASAN}

\section{A. Komunikasi Guru dan Orang Tua Dalam Upaya Optimalisasi Pembelajaran Selama Pandemi}

Tugas orang tua di rumah serta guru di sekolah sangat penting untuk sekolah anak-anak. Jadi komunikasi yang baik antara orang tua dan guru merupakan kebutuhan mutlak untuk mewujudkan kesinergian di antara keduanya. Djamarah seperti dikutip dalam Hidayat mengungkapkan bahwa selama ini anak-anak bersekolah di sekolah, banyak faktor yang mempengaruhi atau mengidentifikasikan dengan prestasi belajar siswa, seperti guru, lingkungan, sarana prasarana, bahkan kerjasama orang tua

\footnotetext{
${ }^{30}$ M. Sari, Ninghardjanti, P., \& Susilowati, T. Komunikasi Guru Dengan Siswa dan Bimbingan Orang Tua, hlm. 3.

31 Z. Matondang, Mengoptimalkan Mutu Proses Pembelajaran Matematika, hlm. 8.
} 
Nur Chayati, Komunikasi Guru dan Orang tua Siswa dalam Mengoptimalkan Pembelajaran

Pada Masa Pandemi di SDI Al-Ittihad Tukum Tekung Lumajang

DOI: htts://doi.org/10.19105/rjpai.v2i2.4774

dengan guru. Pendapat yang lain oleh Mc. Carty, Brennan dan Vecchiarello yang mengungkapkan bahwa sangat mungkin faktor utamanya adalah partisipasi yang dapat diterima oleh orang tua dan sekolah. ${ }^{32}$

Kepala Sekolah SDI Al-Ittihad Fathur Romli menjelaskan, selama pandemi covid-19 ini SDI Al-Ittihan tetap menyelenggarakan kegiatan belajar mengajar, tentu dengan cara daring. Setidaknya ada dua program yang dilaksanakan guna menyiasati pembatasan aktifitas selama pandemi covid-19 ini. Salah satu program yang dilaksanakan SDI Al-Ittihad adalah program guru sambang, dimana guru pro aktif menyambangi rumah-rumah siswa guna melakukan pengawasan dan pendampingan dalam menyelesaikan tugas sekolah yang dibagikan secara daring.

Umi Nadhifah salah satu guru SDI Al-Ittihad menjelaskan program guru sambang, secara praktis dilaksanakan dengan dua model, pertama, guru menyambangi rumah siswa kelasnya secara bergantian selama sepekan. Kedua, terkadang untuk efisiensi guru mengadakan kelompok belajar kecil (2-3 anak per kelompok) yang dilaksanakan secara bergiliran juga di rumahrumah siswa untuk kemudian mendapat pendampingan dari guru kelas masing-masing. Hal ini dilakukan disamping untuk pendampingan proses pembelajaran, juga untuk menjalin interaksi dan komunikasi antara guru dan murid pun demikian dengan oranng tua murid. Komunikasi interpersonal berfungsi menumbuhkan hubungan insan (human relations), Fungsi komunikasi antarpribadi ialah berusaha meningkatkan hubungan insan (human relations), menghindarkan diri dari konflik pribadi, mengurangi ketidakpastian sesuatu, dan juga serta berbagi pengetahuan dan pengalaman dengan orang lain. ${ }^{33}$

Sumaiyah salah satu guru SDI AL-Ittihad menjelaskan, disamping melaksanakan program guru sambang, SDI Al-Ittihad juga membentuk paguyuban wali murid per kelas, dan dibuatkan Whatsapp Group sebagai

32 A. Pusitaningtyas, Pengaruh Komunikasi Orang Tua, hlm. 935.

33 A. Malik, Fungsi Komunikasi antara Guru dan Siswa, hlm., 170. 
RABBANI

wadah silaturrahmi dan komunikasi antara pihak sekolah dan orang tua. Hal ini dilakukan untuk memudahkan dan menjembatani komunikasi dan sosialisasi terkait program pembelajaran, tugas sekolah untuk siswa dan kebutuhan lainnya. Model komunikasi publik melalui Whatsapp Group dipandang sangat efektif dalam menjalin komunikasi antara guru kelas dan wali murid SDI Al-Ittihad.

Komunikasi publik mempunyai fungsi yakni menumbuhkan kembangkan sifat kesetiakawanan (solidaritas), mempengaruhi orang lain, memberikan informasi, menginstruksikan dan terlibat. Untuk individu yang terlibat dengan komunikasi publik, memaksimalkan dengan mengatur diri mereka sendiri dengan pertemuan individu yang sangat besar. Dia berusaha menjadi bagian yang penting untuk pertemuan tersebut sehingga dia sering tergerak oleh pengaruh pertemuan tersebut. Pada saat itu komunikasi massa berfungsi untuk menyebarkan informasi, meratakan pendidikan, menghidupkan perkembangan finansial dan membuat kepuasan dalam hidup seseorang. Bagaimanapun, dalam perkembangan teknologi komunikasi yang begitu pesat, khususnya di bidang penyiaran dan media pandang (audio-visual), menyebabkan fungsi komunikasi massa telah mengalami banyak perubahan.

\section{B. Tantangan Optimalisasi Pembelajaran Selama Pandemi}

Peningkatan sains dan teknologi, perkembangan informasi yang cepat, penemuan dalam teori dan teknik pembelajaran menunjukkan bahwa paradigma lama dalam pembelajaran yang berfokus pada guru sudah saatnya ditinggalkan dan menuju paradigma baru yang melibatkan siswa. Paradigma baru ini mendorong pembelajaran konstruktivisme. ${ }^{34}$

Qoyyum salah satu orang tua siswa menjelaskan, dalam melaksanakan pembelajaran secara daring, tantangan terbesar yang dihadapi oleh guru-

\footnotetext{
34 Syukri Fathudin Achmad Widodo, W. J. Upaya Dosen dalam Optimalisasi, hlm. 4.
} 
Nur Chayati, Komunikasi Guru dan Orang tua Siswa dalam Mengoptimalkan Pembelajaran

Pada Masa Pandemi di SDI Al-Ittihad Tukum Tekung Lumajang

DOI: htts://doi.org/10.19105/rjpai.v2i2.4774

RABBANI guru SDI Al-Ittihad adalah keterbatasan dan kelemahan orang tua siswa dalam mengoperasionalkan gadget ketika mendampingi anaknya selama mengikuti sekolah daring. Pendampingan harus selalu dilakukan oleh orang tua siswa, sebab usia anak sekolah dasar yang masih belum stabil mengharuskan mereka selalu didampingi untuk tetap fokus dalam mengikuti pembelajaran daring. Keluhan yang sama disampaikan Idayani, salah satu orang tua siswa yang menyatakan bahwa, kendala terbesar dengan dirubahnya sistem pembelajaran secara daring adalah, para orang tua siswa menjadi pecah fokus antara mengurusi sekolah anak dan mengurusi pekerjaannya. Ditambah dengan semakin bertambahnya pengeluaran guna membeli pulsa selular selama sekolah daring ini.

Sadikin dan Hamidah pun mengungkapkan masalah ini dalam penelitiannya yang mengungkapkan bahwa tantangan pembelajaran berbasis daring adalah aksesibilitas penyedia internet. Beberapa mahasiswa mengakses internet menggunakan layanan seluler, dan sebagian kecil menggunakan layanan Wi Fi. Ketika strategi pembelajaran berbasis internet dijalankan di Universitas Jambi, mahasiswa pulang kampung. Mereka mengalami masalah sinyal saat berada di daerahnya yang terpisah, terlepas dari apakah sinyal yang mereka dapatkan lemah. Ini adalah tantangan tersendiri dalam penggunaan pembelajaran berbasis internet di Perguruan Tinggi Jambi. Pembelajaran daring memiliki kekurangan ketika layanan internet lemah, dan arahan dosen yang kurang dipahami oleh mahasiswa. Tantangan lain yang dihadapi adalah keharusan dalam mendanai pembelajaran internet. Mahasiswa mengungkapkan bahwa untuk berpartisipasi dalam pembelajaran daring, mereka perlu membayar mahal untuk membeli data internet. Seperti yang ditunjukkan oleh mereka, belajar dalam bentuk konferensi video telah menghabiskan banyak data internet, sementara percakapan online melalui aplikasi pesan instan tidak memerlukan banyak kuota. Pada umumnya, pelajar menghabiskan Rp. 100.000 sampai dengan Rp. 200.000 setiap minggu, bergantung pada provider 
RABBANI

ponsel yang digunakan. Pemanfaatan pembelajaran berbasis internet untuk memahami penggunaan konferensi video membutuhkan biaya sangat mahal. 35

Sadikin dan Hamidah dalam penelitiannya juga mengungkapkan bahwa pembelajaran daring ini memiliki kesulitan yang luar biasa, lokasi siswa dan dosen yang terpisah saat melaksanakannya membuat guru tidak memiliki pilihan untuk langsung mengatur kegiatan siswa selama proses pembelajaran. Tidak ada jaminan bahwa siswa benar-benar mengikuti pembelajaran dan mendengarkan guru. Szpunar, Moulton, dan Schacter merinci dalam peneitian mereka bahwa siswa lebih banyak berfantasi dalam pembelajaran daring daripada pembelajaran tatap muka. Oleh karena itu, disarankan agar pembelajaran daring diadakan dalam waktu yang singkat, mengingat siswa merasa sulit untuk mempertahankan keterikatannya jika pembelajaran daring diadakan selama lebih dari 60 menit. ${ }^{36}$

Orang tua memiliki kendala dalam pembelajaran daring ini yakni masalah siswa ketika belajar di rumah guru memberikan banyak tugas, ada juga guru yang kurang faham cara menggunakan komputer atau laptop, kadang-kadang anak bermain game di handphone pada saat belajar daring. Nugraha menjelaskan bahwa belajar daring ini memiliki kelebihan yakni waktu dan tenaga dapat diminimalisisr. Sehingga waktu dan tenaga yang masih ada dapat digunakan untuk melakukan kegiatan yang lain diluar kelas online. ${ }^{37}$

Selain memiliki masalah dalam pembelajaran daring, dari satu perspektif pembelajaran daring juga memiliki keuntungan. Berkenaan dengan sebagian keuntungan dari pembelajaran internet, untuk lebih spesifiknya cenderung dilakukan kapanpun dan dimanapun tempat belajar misalnya, pembelajaran

\footnotetext{
35 Sadikin, A., \& Hamidah, A. Pembelajaran Daring di Tengah Wabah Covid-19 (Biodik, 6 (2), 2020), hlm. 218.

36 Ibid., hlm. 219.

37 Putri, A. P., Rahhayu, R. S., Meidawati, S., \& Ningsih, P. A. R. Strategi Pembelajaran Melalui Daring dan Luring Selama Pandemi (Prima Magistra: Jurnal Ilmiah Kependidikan, 2021), hlm. 2.
} 
Nur Chayati, Komunikasi Guru dan Orang tua Siswa dalam Mengoptimalkan Pembelajaran

Pada Masa Pandemi di SDI Al-Ittihad Tukum Tekung Lumajang

DOI: htts://doi.org/10.19105/rjpai.v2i2.4774

dapat dilakukan di kamar, ruang tamu, dan lain sebagainya serta waktu disesuaikan misalnya pagi, siang, sore atau malam. Demikian pula, pembelajaran daring juga dapat dicapai meskipun jaraknya jauh, demikian pula tidak perlu pergi ke kelas terlebih dahulu untuk belajar mereka ada dimana saja dan dapat mengakses pembelajaran daring. Selain menikmati keuntungan, pembelajaran internet juga memiliki kelemahan.

Orang tua adalah mitra kerja yang mendasar bagi pendidik di sekolah anak-anak. Komunikasi yang berhasil antara orang tua dan pendidik diperlukan untuk menyesuaikan pandangan kedua belah pihak tentang apa yang diperlukan di sekolah anak-anak. Keduanya harus saling membantu dan menyadari bagaimana menangani anak di sekolah, keterikatan siswa dalam pendidik dalam pembelajaran, pola interaksi dan komunikasi selama sekolah dan masalah yang ditemukan di sekolah. Apalagi sekolah mengetahui apa dan bagaimana yang terjadi di rumah, terutama diidentikkan dengan kegiatan bermain anak di luar rumah, aktivitas pembelajaran di rumah, kerjasama dengan anggota keluarga yang lain dan masalah yang muncul selama di rumah. ${ }^{38}$

Di tempat lain juga terdapat temuan yang hampir sama yakni hasil penelitian di SMA Negeri 2 Sukamaju diketahui bahwa bentuk komunikasi yang dilakukan orang tua dengan guru dalam proses pengukuhan karakter siswa, misalnya ketika ada pembagian rapor, sekolah tidak memberi langsung rapor tersebut kepada orang tua melainkan sekolah membuat surat yang akan dibagikan kepada orang tua dan juga sekolah menyampaikan bagaimana kegiatan anak ketika di sekolah. Kegiatan seperti ini sudah menjadi kebiasaan setiap akhir semester agar hubungan kerjasama antara sekolah dengan orang tua dalam proses pengukuhan karakter siswa saat ada masalah atau pelanggaran yang dilakukan siswa. ${ }^{39}$

\footnotetext{
38 A. Pusitaningtyas, Pengaruh Komunikasi Orang Tua, hlm. 938.

39 P. Lestari, Pola Komunikasi Guru dan Orang Tua dalam Pembinaan Akhlak Peserta Didik (IQRO: Journal of Islamic Education, 1 (1), 2018), hlm. 95.
} 
Sebagai penelaahan sejauh mana melaksanakan pembelajaran melalui media online, hasil penelitian Fitria Novita Sarie menunjukkan bahwa evaluasi pembelajaran melalui WA selama satu semester, pembelajaran daring melalui WA dianggap membosankan siswa karena tidak dilengkapi dengan fitur-fitur yang lengkap. Para pelajar kurang bersemangat karena mereka hanya memahami pesan dan menggunakan catatan suara, percakapan sesama teman juga dirasa kurang ideal sehingga beberapa siswa saja yang ikut serta aktif saat pembelajaran daring. Penelitian Dewi (2020) menunjukkan bahwa pandemi virus corona berpengaruh signifikan terhadap pelaksanaan pembelajaran berbasis internet di sekolah. Salah satu penyebab terhambatnya pembelajaran daring ini adalah sarana yang kurang lengkap seperti handphone dan kuota internet. Hasil penelitian Sari (2019) memperjelas bahwa pemanfaatan e-learning berbasis Edmodo terbukti berhasil meningkatkan kemampuan komunikasi matematika. Kedua penelitian ini adalah alasan untuk memilih Edmodo dalam pembelajaran daring di sekolah dasar. ${ }^{40}$

Komunikasi dalam lingkungan keluarga tentunya memiliki berbagai implikasi yang berbeda dengan komunikasi dalam lingkungan sosial yang lebih luas, dan sebaliknya dalam lingkungan keluarga, karena satu kelompok keluarga dengan kelompok keluarga lainnya jelas memiliki metode komunikasi yang dibangun dalam lingkup setiap kelompok keluarga. Ada dampak positif yang sangat besar antara intensitas komunikasi di kalangan anak dan orang tua dengan motivasi belajar siswa. Pada tingkat dasar, anak-anak bergantung pada bagaimana keadaan lingkungan keluarga, karena bagaimanapun keluarga adalah pendidikan utama bagi anak. ${ }^{41}$

\footnotetext{
${ }^{40}$ F. N. Sarie, Optimalisasi Pembelajaran Daring Masa Pandemi Covid-19 Melalui Aplikasi Edmodo bagi Peserta Didik Sekolah Dasar (Jurnal Pendidikan Dasar: Jurnal Tunas Nusantara, 2 (2), 2020), hlm. 250.

${ }^{41}$ Candra dan Sakban, Hubungan Antara Pola Komunikasi Orang Tua, hlm. 82.
} 
Nur Chayati, Komunikasi Guru dan Orang tua Siswa dalam Mengoptimalkan Pembelajaran

Pada Masa Pandemi di SDI Al-Ittihad Tukum Tekung Lumajang

DOI: htts://doi.org/10.19105/rjpai.v2i2.4774

RABBANI

Dalam masa pandemi seperti ini, pengajar perlu memiliki kemampuan sosial untuk membantu kelangsungan pelaksanaan interaksi pembelajaran. Melalui kapasitas ini, keterkaitan antara sekolah dan lingkungan sekitar akan berjalan dengan baik, dengan tujuan agar keterkaitan antara sekolah dan lingkungan sekitar yang bermanfaat secara umum dapat berjalan secara sinergis. Keterampilan sosial harus dibangun bersama dengan kemampuan pendidik untuk menyampaikan, berkoordinasi, bergaul, dan memiliki jiwa yang menyenangkan. Sejalan dengan itu, inti dari kemampuan sosial terletak pada komunikasi, namun komunikasi yang dimaksud adalah komunikasi yang efektif. Komunikasi dapat dicirikan sebagai interaksi yang berdampak bersama antarmanusia. Komunikasi juga merupakan keseluruhan dari perasaan, perspektif dan ekspektasi baik yang disampaikan secara langsung ataupun tidak langsung, terlepas dari apakah dilakukan dengan sengaja atau tidak sebab komunikasi adalah elemen penting dari proses perubahan. ${ }^{42}$

\section{KESIMPULAN}

Orang tua dan guru mempunyai peran yang sangat penting terhadap pendidikan anak. Ada dua program yang dilaksanakan SDI Al-Ittihad guna menyiasati pembatasan aktifitas selama pandemi covid-19 ini. Salah satu program adalah program guru sambang, dimana guru menyambangi rumah-rumah siswa guna melakukan pengawasan dan pendampingan dalam menyelesaikan tugas sekolah yang dibagikan secara daring. Program guru sambang, secara praktis dilaksanakan dengan dua model: pertama, guru menyambangi rumah siswa kelasnya secara bergantian selama sepekan. Kedua, terkadang untuk efisiensi guru mengadakan kelompok belajar kecil (2-3 anak per kelompok). SDI Al-Ittihad juga membentuk paguyuban wali murid per kelas, dan dibuatkan Whatsapp Group sebagai bentuk komunikasi antara pihak sekolah dan orang tua. Model komunikasi publik melalui Whatsapp Group dipandang sangat efektif dalam menjalin

42 Imron Fauzi, Etika Profesi Keguruan (Jember: IAIN Jember Press, 2019). 
Nur Chayati, Komunikasi Guru dan Orang tua Siswa Dalam Optimalkan Pembelajaran Pada Masa Pandemi di SDI Al-Ittihad Tukum Tekung Lumajang DOI: htts://doi.org/10.19105/rjpai.v2i2.4774

RABBANI

komunikasi antara guru kelas dan wali murid. Ada pula tantangan yang harus dihadapi guru dan orang tua terbesar adalah keterbatasan dan kelemahan orang tua siswa dalam mengoperasionalkan gadget ketika mendampingi anaknya selama mengikuti sekolah daring. Pendampingan harus selalu dilakukan oleh orang tua siswa, sebab usia anak sekolah dasar yang masih belum stabil mengharuskan mereka selalu didampingi untuk tetap fokus dalam mengikuti pembelajaran daring. Kendala orang tua dalam menghadapi pembelajaran daring ini banyak yang mengeluhkan beberapa masalah yang dihadapi selama peserta didik belajar dirumah, salah satunya guru memberikan banyak tugas yang diberikan, guru kurang menguasai IT, dan tidak efektifnya pembelajaran di rumah anak sering bermain game di gadget setiap saat. Ditambah dengan semakin bertambahnya pengeluaran guna membeli pulsa dan kuota selama sekolah daring ini.

\section{DAFTAR PUSTAKA}

Baharuddin. Pengaruh Komunikasi Orang Tua terhadap Perilaku Anak pada MIN I Lamno Desa Pante Keutapang Aceh Jaya. Jurnal AL-IJTIMAIYYAH: Media Kajian Pengembangan Masyarakat Islam, 2019.

Budi, R. Pengantar Ilmu Komunikasi. In Jurnal Pendidikan (I, Vol. 2, Issue 2). KRETAKUPA Print Makassar, 2017.

Candra, \& Sakban, A. Hubungan Antara Pola Komunikasi Orang Tua Dengan Motivasi Belajar Siswa di SMAN 1 Labuapi Lombok Barat. JUPE Jurnal Pendidikan Mandala, 2017.

Fauzi, Imron. Etika Profesi Keguruan. Jember: IAIN Jember Press, 2019.

Kulsum, D. U. Optimalisasi Penggunaan Buku Teks Dalam Upaya Meningkatkan Prestasi Belajar Di SMP. Jurnal Manajemen Pendidikan, 2015.

Kusumawati, N. M. Optimalisasi Model Pembelajaran Berbasis Masalah Dengan Berbantuan Lembar Kerja Siswa (Lks) Untuk Meningkatkan Aktivitas Dan Hasil Belajar Dalam Mata Pelajaran Matematika. Journal of Education Action Research, 2017. 
Nur Chayati, Komunikasi Guru dan Orang tua Siswa dalam Mengoptimalkan Pembelajaran

Pada Masa Pandemi di SDI Al-Ittihad Tukum Tekung Lumajang

DOI: htts://doi.org/10.19105/rjpai.v2i2.4774

Lestari, P. Pola Komunikasi Guru dan Orang Tua dalam Pembinaan Akhlak Peserta Didik. IQRO: Journal of Islamic Education, 2018.

Ma`arif, M. A. (n.d.). Optimalisasi Pembelajaranpendidikan Islam di Sekolah/Madrasah: Upaya dan Faktor Penghambat Pembelajaran Pendidikan Islam. Falasifa.

Malik, A. Fungsi Komunikasi Antara Guru dan Siswa dalam Meningkatkan Kualitas Pendidikan (Studi Kasus Proses Belajar Mengajar pada SMP Negeri 3 Sindue). INTERAKSI: Jurnal Ilmu Komunikasi, 2014.

Matondang, Z. Mengoptimalkan Mutu Proses Pembelajaran Matematika Di Kelas. Jurnal Character Building, 2010.

Megawati, M., \& Kahar, F. Pengaruh Komunikasi Orang Tua Dengan Guru terhadap Peningkatan Kualitas Pembelajaran. Jurnal Office, 2017.

Nasional, P. B. D. P. Kamus Bahasa Indonesia. In Pusat Bahasa (Vol. 4, Issue 3), 2008.

Nazarudin, M. Pola Kerjasama Guru dan Orang Tua dalam Meningkatkan Mutu Pendidikan di MIN 2 Kota Palembang. Intizar, 2018.

Prayoga, A. G., Benty, D. D. N., \& Kusumaningrum, D. E. Kerjasama guru dan orang tua dalam peningkatan budi pekerti pesera didik di SDI Plus Al Minhaaj Wates Kediri. Digital Repository Universitas Negeri Malang, 2017.

Pusitaningtyas, A. Pengaruh Komunikasi Orang Tua dan Guru terhadap Kreativitas Siswa. Proceedings of the ICECRS, 2017.

Putri, A. P., Rahhayu, R. S., Meidawati, S., \& Ningsih, P. A. R. Strategi Pembelajaran Melalui Daring Dan Luring Selama. Prima Magistra: Jurnal Ilmiah Kependidikan, 2021.

Sadikin, A., \& Hamidah, A. Pembelajaran Daring di Tengah Wabah Covid-19. Biodik, 2020. 
RABBANI

Sardjiyo. Optimalisasi Penggunaan Media Pembelajaran Sebagai Wujud Inovasi Belajar Yang Bermakna Dalam Pengembangan Karakter Peserta Didik (Kasus Pembelajaran di SDN X Kabupaten Bandung). Prosiding Temu Ilmiah Nasional Guru (TING) VIII, November, 2016.

Sari, H. M., Ninghardjanti, P., \& Susilowati, T. Komunikasi Guru Dengan Siswa dan Bimbingan Orang Tua Terhadap Motivasi Belajar Siswa. Jurnal Pendidikan Administrasi Perkantoran, 2013.

Sarie, F. N. Optimalisasi Pembelajaran Daring Masa Pandemi Covid-19 Melalui Aplikasi Edmodo Bagi Peserta Didik Sekolah Dasar. Jurnal Pendidikan Dasar : Jurnal Tunas Nusantara, 2020.

Siolemba, A. S. Koordinasi Berbasis Media Sosial antara Orang Tua dan Guru dalam Pengawasan Pembelajaran Siswa (Studi Kasus: SMP Kristen Satya Wacana Salatiga). Artikel Ilmiah Repository UKSW, 2016.

Syukri Fathudin Achmad Widodo, W. J. Upaya Dosen Dalam Optimalisasi Pembelajaran Ditinjau Dari Heterogenitas Karakteristik Mahasiswa. Journal of Chemical Information and Modeling, 1970.

Zaini, A. Optimalisasi Ketercapaian Standar Proses Pembelajaran untuk Meningkatkan Mutu Pendidikan di SMPN Pamekasan. Jurnal Pendidikan, 2013. 